\title{
Phytochemical and anti-nutritional studies on some commonly consumed fruits in lokoja, kogi state of Nigeria
}

\author{
Ekpa Emmanuel* and Sani Deborah \\ Department of Biosciences, Salem University Lokoja, Nigeria
}

\begin{abstract}
Phytochemical and anti-nutritional studies were carried out on fresh fruits of Apple (Malus sylvestris), Pawpaw (Carica papaya), watermelon (Citrullus vulgaries), and Pineapple (Ananus comasus) purchased from some road side vendors in Lokoja, Kogi State of Nigeria. Phytochemical screening using standard methods showed that phenols, alkaloide, tannins, and quinones were high in all the fruits tested while anti-nutritional studies using the AOAC methods recorded series of values for some of the quantified anti-nutrients. Phytates and tanins in the apple fruit were found to have the highest values of $1.51 \pm 0.02 \%$ and $1.95 \pm 0.01 \%$ respectively. Hydrogen cyanide was significantly lower in all the fruits with pawpaw recording the lowest value of $0.005 \pm 0.003$. Trypsin inhibitor was highest in water melon with a value of $1.09 \pm 0.03 \mathrm{TIU} / \mathrm{mg}$. The value of saponins were observed to be low across the fruits, whereas those of alkaloid falls within tolerable limit. The implication of these findings shows that these anti-nutrients are not within harmful ranges, as such they cannot interfere with potentially useful nutrients embedded in these fruits and thus are fit for human consumption.
\end{abstract}

\section{Introduction}

Anti-nutritional factors are those substances or chemical compounds found in fruits and food substances in general. They are poisonous to humans or in some ways limit nutrients availability to the body [1]. Anti-nutritional factors are present in different food substances in varying amounts depending on the kind of food, mode of its propagation, chemicals used in growing the crop as well as those chemicals used in storage and preservation of the food substances. These anti-nutritional factors are known to interfere with metabolic processes such that growth and bioavailability of nutrients are negatively influenced [2]. Examples of anti-nutritionals factors present in most fruits are alkaloids, tannins, phytate, trypsin inhibitor, cyanide, saponins, and oxalates. Phytate and oxalates have the ability to form chelates with di- and trivalent metallic ions such as $\mathrm{Cd}, \mathrm{Mg}, \mathrm{Zn}$, and $\mathrm{Fe}$ to form poorly soluble compounds that are not readily absorbed from the gastrointestinal tract thus reducing their bioavailability [3]. Antinutritional factors reduce the nutrient utilization and/or food intake of plants or plant products used as human foods or animal feeds and they play a vital role in determining the use of plants for humans and animals [4]. Apart from cyanogenic glycosides, food poisoning arising from anti-nutritional factors, otherwise known as plants' secondary metabolites has not been properly addressed in most parts of the developing world. People have died out of ignorance, poverty and inadequate nutrition information and education, especially within subSaharan African regions. There are reports from time to time of deaths after consumption of some type of beans despite cooking. Also, cases of renal and liver diseases are increasing and this call for a need to properly address the issue of thorough and inadequate processing of foods/feeds before consumption. There is a wide distribution of biologically-active constituents throughout the plant kingdom, particularly in plants used as animal feeding stuff and in human nutrition [5]. The knowledge that these compounds elicit both toxic and advantageous biological responses has given rise to several investigations in recent times as to their possible physiological implications in various biological systems.
It is well known that plants generally contain anti- nutrients acquired from fertilizer and pesticides and several naturally-occurring chemicals [1]. Some of these chemicals are known as "secondary metabolites" and they have been shown to be highly biologically active. They include saponins, tannins, flavonoids, alkaloids, trypsin (protease) inhibitors, oxalates, phytates, haemagluttinins (lectins), cyanogenic glycosides, cardiac glycosides, coumarins and gossypol.

The term fruits have different meaning. Botanically, a fruit is the ripened ovary together with seeds of a flowering plant. In many species, the fruit incorporates the ripened ovary and surrounding tissues. Fruit are the means by which flowering plant disseminate seeds, in cuisine fruits that are sweet and fleshy, examples of which include apple and orange [4]. However, a great many common fruits as well as nuts and grins are the fruit of the plant species they come. Majority of the fruit are fleshly or juicy. Fruits are important sources of nutrients which include carbohydrates, fiber, oils, proteins, minerals, antioxidant phenols, and vitamins which are essential for normal growth and development of body tissues for the human health. In addition, it is known that some fruits have so called "anti-nutritional" factors such as phytate, tannins, and oxalate that can diminish the nutrient bioavailability, especially if present at high level [6]. Although, it has been reported that these anti-nutritional factors could help to prevent and treat several diseases; remarkably, the anti-carcinogenic activity of phytate, and the antidiarrheal activity of tannins. Plant foods are the only sources of dietary fiber which plays an important role in decreasing the risk of many disorders such as constipation, diabetes, cardiovascular diseases, and obesity. Plant polyphenols are known for lowering the risk of several

${ }^{\star}$ Correspondence to: Ekpa Emmanuel, Department of Biosciences, Salem University Lokoja, Nigeria, Tel: +2347036135834; E-mail: emmeks@yahoo.co.uk

Key words: phytochemicals, antinutritional factors, fruits, Lokoja

Received: May 12, 2018; Accepted: May 23, 2018; Published: May 25, 2018 
oxidative stresses including cardiovascular diseases, cancer, stroke and ageing [7]. Factors that determine the nutritive value of foods are very complex. All available information, both qualitative and quantitative must be used in making judgments about the food value of particular plant species. The fact that a plant or part of a plant is eaten by human is only an indication of acceptability. Certain harmful effects might also be due to the breakdown products of these compounds. However, some anti-nutritional factors as well as their break down products may possess beneficial health effects if present in small amounts. The mechanism through which the anti-nutritional and beneficial effects of food anti-nutritional factors are exerted is the same. Thus, manipulating processing conditions, in addition to removing certain unwanted compounds in foods, may be required to eliminate the deleterious effects of anti-nutritional factors and take advantage of their health benefits. The main goal of this work therefore was to perform phytochemical screening and antinutritional studies on some commonly consumed roadside vended fruits in Lokoja, Nigeria so as to determine the antinutritional factors in them. This is with a view to understanding the health implication of their consumption or otherwise.

\section{Materials and methods}

All reagents used in this work were of analytical grade and purchased from authentic sources.

\section{Collection of plant samples}

Three kilograms of four fresh and fully ripe fruits (pawpaw (Carica pawpaw), pineapple, (Ananas cosmos) apple (Malus sylvestris), and watermelon (Citrullus lanatus) ) were purchased from some road side fruit Vendors along Ganaja district of Ajaokuta Local Government of Kogi State, Nigeria. They were immediately transported to the Laboratory in ice packed polythene bags.

\section{Preparation of fruit peels}

Fresh fruits were washed and allowed to dry at room temperature. For pawpaw, apple, and pineapple, all the peel was removed using a sharpened knife. For watermelon, only the colored part of the peel was carefully peeled to minimise the inclusion of albedo which is an inner layer of spongy white tissue. Each was separately blended using some quantity of distilled water at $20^{\circ} \mathrm{C}$ in a normal kitchen blender and subsequently stored in a refrigerator for further analysis.

\section{Qualitative determination of the Anti-nutrients (AOAC, 2000)}

\section{Saponin}

Two grams of the sample was added toabout $5 \mathrm{ml}$ of distilled water in a test tube and the mixture shaken vigorously, then placed in a water bath for some minutes. Formation of foamy like liquid at the top of the mixture confirms the presence of saponin.

\section{Alkaloids}

In this test, Maeyers' reagent (a solution of $1.3 \mathrm{~g} \mathrm{HgCl}_{2}$ and $5 \mathrm{~g} \mathrm{KI}$ in $100 \mathrm{ml}$ of distilled water) was added to about $2 \mathrm{ml}$ of concentrated $\mathrm{HCl}$ and $1 \mathrm{ml}$ of the blended sample dropwise. Formation of a creamy-like precipitate confirms the presence of alkaloids.

\section{Quinone}

One millilitre $(1 \mathrm{ml})$ of concentrated $\mathrm{H}_{2} \mathrm{SO}_{4}$ was mixed with about $2 \mathrm{ml}$ of the sample solution. Appearance of red coloured product indicates the presence of quinones.

\section{Cardiac glycosides}

About $4 \mathrm{ml}$ of the sample solution was added to $2 \mathrm{ml}$ glacial acetic acid in a test tube and a few drops concentrated $\mathrm{H}_{2} \mathrm{SO}_{4}$ was let down the mixture in a test tube. Formation of ring at the interface confirmed the presence of a deoxy sugar characteristic of cardiac glycosides.

\section{Phenol}

In this test, $2 \mathrm{ml}$ of distilled water was added to $1 \mathrm{~g}$ of sample and then some drops of $10 \%$ ferric chloride added.Formation of blue or green colour confirms the presence of phenols.

\section{Phlobatanins}

About $4 \mathrm{ml}$ of the sample was boiled together $1 \% \mathrm{HCl}$ in a test tube. Red precipitate formation indicates the presence of phlobatanins.

\section{Tanins}

About $1 \mathrm{~g}$ of the sample was boiled with $20 \mathrm{ml}$ distilled water in a test tube and then filtered. Some drops of $0.1 \%$ ferric chloride was added and monitored for appearance of blue-black colouration which shows the presence of tanins.

\section{Quantitative determinations of the anti-nutrients}

Determination of hydrogen cyanides content: The hydrogen cyanide content in fruit peels was determined by the procedure described by AOAC (2000). Five grams of sample was incubated for 16 hours at a temperature of $35^{\circ} \mathrm{C}$. after this extraction, filtration was carried out using a specially prepared filter paper and quickly followed by distillation in Markham distillation apparatus. The sample was then transferred a double necked flask with a steam source. the entire content was distilled with saturated sodium bicarbonate solution for about 1 hour. One millilitre of starch indicator was added to $30 \mathrm{ml}$ of the distillate and finally titrated with $0.2 \mathrm{~N}$ of $\mathrm{NaOH}$ solution.

Oxalate Determination by Titration Method: This determination involved three major steps: digestion, oxalate precipitation and permanganate titration.

\section{Digestion}

i) $2 \mathrm{~g}$ of sample was suspended in $190 \mathrm{ml}$ of distilled water in a $250 \mathrm{ml}$ volumetric flask.

ii) $10 \mathrm{ml}$ of $6 \mathrm{M} \mathrm{HCl}$ was added and the suspension digested at $100^{\circ} \mathrm{C}$ for 1 hour.

iii) The solution was cooled, and then made up to $250 \mathrm{ml}$ mark before filtration.

\section{Oxalate Precipitation}

Duplicate Portions of the filtrate were measured into breakers and four drops of methyl red indicator added. Then $\mathrm{NH}_{4} \mathrm{OH}$ solution was added (drop wise) until the test solution changed from pink to faints yellow colour (PH4.0-4.5). Each portion was then heated to $90^{\circ} \mathrm{C}$, cooled and filtered to remove precipitate containing ferrous ion. The filtrate was again heated to $90^{\circ} \mathrm{C}$ and $10 \mathrm{ml}$ of $5 \% \mathrm{CaCl}_{2}$ solution was added while being stirred constantly. The solution was then heated and left overnight at $25^{\circ} \mathrm{C}$, it was then centrifuged at $2500 \mathrm{rpm}$ for 5 minutes. The supernatant was decanted, and the precipitate completely dissolved in $10 \mathrm{ml}$ of $20 \%(\mathrm{v} / \mathrm{v}) \mathrm{H}_{2} \mathrm{SO}_{4}$ solution.

\section{Permanganate Titration}

At this point, the total filtrate resulting from digestion of $2 \mathrm{~g}$ of sample was made up to $300 \mathrm{ml}$. Aliquots of $125 \mathrm{ml}$ of the filtrate was 
heated until near boiling and then titrated against $0.05 \mathrm{M}$ standardized $\mathrm{KMnO}_{4}$ solution to a faint pink colour which persisted for 30 seconds. The calcium oxalate content was calculated using the formula:

$$
\frac{T \times(V m e)(D f)}{\left(M E \times M_{F}\right)} \times(M g / 100 g)
$$

Where $\mathrm{T}$ is titre of $\mathrm{KMnO}_{4}(\mathrm{ml})$

$\mathrm{V}_{\mathrm{me}}$ is the volume-mass equivalent

$\mathrm{Df}$ is the Dilution factor $=\mathrm{Vt} / \mathrm{A}$

Where Vt is the total volume of filtrate $(300 \mathrm{ml})$ and $\mathrm{A}$ is the aliquot used i.e. $250 \mathrm{ml}$,

$\mathrm{ME}$ is the molar equivalent of $\mathrm{KMnO}_{4}$ in oxalate and

$\mathrm{M}_{\mathrm{F}}$ is the mass of sample used

\section{Alkaloid determination}

Five grams of the sample was weighed into a $250 \mathrm{ml}$ beaker and $200 \mathrm{ml}$ of $20 \%$ acetic acid in ethanol was added and covered and allowed to stand for 4 hours at $25^{\circ} \mathrm{C}$. It was then filtered and the filtrate was concentrated using waterbath (memmert) to one -quarter of the original volume. Concentrated ammonium hydroxide was added drop wise to the extract until the precipitation was complete. The whole solution was allowed to settle and the precipitate was collected and washed with dilute $\mathrm{NH}_{4} \mathrm{OH}$ solution. Itwas then filtered using a pre-weighed filter paper. The residue on the filter paper is the alkaloid and was dried in the precision oven at $80^{\circ} \mathrm{C}$. The alkaloid content was calculated and expressed as a percentage of the weight of the sample analyzed, thus:

$$
\% \text { Weight of alkaloid }=\frac{\text { Wt of filter paper with residue }- \text { wt of filter paper }}{\text { Weight of sample analyzed }} \times 100
$$

\section{Determination of Saponin}

Five grams of the sample was put into $20 \%$ acetic acid in ethanol and allowed to stand in water bath at $500^{\circ} \mathrm{C}$ for 24 hours. This was filtered, and the extract was concentrated using a water bath to one-quarter of the original volume. Concentrated $\mathrm{NH}_{4} \mathrm{OH}$ was added drop-wise to the extract until the precipitation was complete. The whole solution was allowed to settle, and the precipitate was collected by filtration and weighed. The saponin content was weighed and calculated in percentage of sample analyzed.

$$
\% \text { Saponin content }=\frac{(\text { Wt of filter paper }+ \text { residue })-(w t \text { of filter paper })}{\text { Weight of sample analyzed }} \times 100
$$

\section{Tannin Determination by Titration}

The Follins Dennis titrating method as described by Pearson (1974) was used. To $20 \mathrm{~g}$ of the crushed sample in a conical flask was added $100 \mathrm{mls}$ of petroleum ether and covered for 24hours. The sample was then filtered and allowed to stand for 15 minutes so that the petroleum ether evaporated. It was re-extracted by soaking in $100 \mathrm{ml}$ of $10 \%$ acetic acid in ethanol for 4 hours. The sample was then filtered and the filtrate collected. $25 \mathrm{ml}$ of $\mathrm{NH}_{4} \mathrm{OH}$ were added to the filtrate to precipitate the alkaloids. The alkaloids were heated with electric hot plate to remove some $\mathrm{NH}_{4} \mathrm{OH}$ still in solution. The remaining volume was measured. $5 \mathrm{ml}$ of this volume was taken and $20 \mathrm{ml}$ of ethanol was added to it. It was titrated with O.IM NaOH using phenolphthalein as indicator until pink end point is reached. Tannin content was then calculated in percentage molarity of the sample analysed.

\section{Calculation:}

$$
\begin{aligned}
& C_{1} V_{1}=C_{2} V_{2} \\
& C_{1=} C_{2} V_{2} / V_{1} \\
& \% \text { of tannic acid content }= \\
& \text { Where } C_{1}=\text { Conc. Of tannic acid } \\
& C_{2}=\text { Conc. Of Base } \\
& V_{1}=\text { Volume of Tannic acid } \\
& V_{2}=\text { Volume of Base used }
\end{aligned}
$$$$
\% \text { of tannic acid content }=\frac{C_{1} \times 100}{\text { Wt of sample analyzed }}
$$

\section{Phytate Determination}

The method used was the Young and Greaves method (1940) as adopted by Lucas Markakes (1975). $0.2 \mathrm{~g}$ of the sample was weighed into $250 \mathrm{ml}$ conical flask. It was soaked in $100 \mathrm{ml}$ of $20 \%$ concentrated $\mathrm{HCl}$ for 3 hours, the sample was then filtered $50 \mathrm{ml}$ of the filtrate was placed in a $250 \mathrm{ml}$ beaker and $100 \mathrm{ml}$ distilled water added to the sample. Then $10 \mathrm{ml}$ of $0.3 \%$ ammonium thiocyanate solution was added as indicator and titrated with standard iron (III) chloride solution which contained $0.00195 \mathrm{~g}$ iron per $1 \mathrm{ml}$.

\section{Calculation:}

$$
\text { Phytic aicd }=\frac{\text { Titre value } \times 0.00195 \times 1.19 \times 100}{2}
$$

\section{Determination of Trypsin Inhibitor}

$0.5 \mathrm{~g}$ of sample was extracted with $50 \mathrm{ml}$ of distilled water for 30 minutes with mechanical shaking at a speed of $200 \mathrm{rpm}$. $10 \mathrm{ml}$ of the sample suspension was then destabilized by adding an equal volume of assay buffer and vigorously shaking for 2-3 minutes before filtering through a What No.2 filter paper. The filtrate was then further diluted with water to the point where $1 \mathrm{ml}$ gave $30-79 \%$ trypsin inhibitor. This was done to keep the relative standard deviation (RSD) of trypsin inhibitor activity (TIA) measured within $\pm 3.5 \%$. A suitable final concentration of the sample was around $0.1 \mathrm{mg}$ of the sample per $\mathrm{ml}(0.1 \mathrm{mg}$ sample/ $\mathrm{ml}$ diluted extract), and for heated sample, it is $0.5-1.5 \mathrm{mg} / \mathrm{ml}$. The reaction was run at $37^{\circ} \mathrm{C}$. Exactly 10 minutes after adding the trypsin solution, the reaction was stopped by injecting $0.5 \mathrm{ml}$ of $30 \%$ acetic acid solution with 1-ml syringe. The absorbance at AS410 (Sample reading), was a measure of the trypsin activity in the presence of the sample inhibitors. The reaction was also run in the absence of inhibitors by replacing the sample with $1 \mathrm{ml}$ of water. The corresponding absorbance was symbolized as Ar 410(reference reading). Distilled water was then used as a blank.

\section{Calculation}

Defining a trypsin unit as an A410 increase of 0.01 under the conditions of the assay, the trypsin inhibitory activity is expressed in Trypsin units inhibited (TUI) Per milligram of the sample and calculated as follows:

$$
\text { TUI } / \text { mg sample }=\frac{\left(A_{410}^{r}-A_{410}^{S}\right) \times 100 / \mathrm{ml} \text { diluted extract }}{(\mathrm{mg} \text { sample } / \mathrm{ml} \text { diluted extract })}
$$

\section{Results and Discussion}

Seven phytochemical components were found in the freshly blended pulp of Pineapple (Ananus comosus), Watermelon (Citrullus vulgaris L.), Pawpaw (Carica papaya), Apple (Malus sylvestris) used 
for this work. They included saponins, alkaloids, tannins, phytates, oxalate, phenols, and HCN. The highest content of all the antinutritional factors detected was in the tanins and phytate contents of these fresh fruits. Apple and pineapple recorded a high value of most of the phytochemicals quantitatively determined than the other fruits although the values were lower compared to earlier work [Tables 2-5]. The high tanins and phytates noticed in most of the fruits agrees with the findings of Abdel et al., (2007) who reported that naturally occurring phytic and tannic acid in fruits with antioxidant, anti-inflammatory and diuretic effect is due to their high fiber content as is observed in the pulp of water melon and apple in this study [8]. The toxic levels of these anti-nutrients however have not been established as reported by Awe and Sodipo (2001) [9]. They also stressed that saponins have bitter taste and can reduce fruit palatability, some of which are toxic to humans at a particular concentration. Cardiac glycosides and quinones were almost absent in all the fruits used for this work [Table 1]. In 1991 however, $\mathrm{FAO} / \mathrm{WHO}$ recommended that HCN levels in mammals should be $10 \mathrm{mg} / \mathrm{kg}$ dry weight $(10 \mathrm{ppm})$ which was much than what was obtained in this study. Fergusin et al, (1993) reported that phytic acid intake of $4-9 \mathrm{mg} / 100 \mathrm{~g}$ is said to decrease iron absorption by $4-5$ folds in humans and the lethal level of oxalate in man is 3-5g as reported by FAO (1985) [4-10]. Recently, (2012) reported that a daily intake of 450mg of oxalic acid has been reported to interfere with various metabolic processes [11]. The values obtained for phytate and oxalate are lower than the lethal dosage reported in other studies while the toxic effect of these anti-nutrients may not occur when these fruits are consumed because their levels are not enough to elicit toxicity. Tannins are known to affect the digestive tracts and their metabolites are toxic [5]. The precise toxic amount of tannin that can cause depression in human is not known, but the values obtained for these phenolic substances is within the range of $0.03 \mathrm{mg}-1.72 \mathrm{mg} / 100 \mathrm{~g}$. From previous studies, it has been observed that Hydrogen cyanide is an extremely poisonous substance formed by the action of acids on metal cyanides. Large dose of hydrogen cyanide can cause death within few minutes, while smaller dosages may result to stiffness of the throat, chest, palpitation and muscle weakness. The result obtained in this study falls within the threshold value as it could not even be detected making the fruits safe for human consumption. Phytic acid found in plant materials is known for its chelating effect on certain essential mineral elements such as $\mathrm{Ca}, \mathrm{Mg}, \mathrm{Fe}$ and $\mathrm{Zn}$ to form insoluble phytate salts. In humans, phenolic compounds have been reported to exhibit a wide range of biological effects including

Table 1. Phytochemical analysis of the Blended fruits

\begin{tabular}{|c|c|c|c|c|}
\hline Anti-nutrient & Apple & Watermelon & Pawpaw & Pineapple \\
\hline Phenol & + & ++ & ++ & + \\
\hline Tanin & + & + & ++ & + \\
\hline Saponin & + & + & + & + \\
\hline Alkaloid & + & ++ & + & ++ \\
\hline Pholbatanin & - & + & -- & -- \\
\hline Quinone & + & + & ++ & + \\
\hline Cardiac glycoside & -- & -- & -- & -- \\
\hline
\end{tabular}

Table 2. Anti-nutritional contents of Blended Apple fruit

\begin{tabular}{|c|c|}
\hline Anti-nutrient & Amount (\%) \\
\hline Phytate & $1.51 \pm 0.02$ \\
\hline Tanin & $1.95 \pm 0.01$ \\
\hline Saponin & $0.46 \pm 0.01$ \\
\hline Alkaloid & $0.90 \pm 0.01$ \\
\hline Hydrogen Cyanide & $0.006 \pm 0.004$ \\
\hline Trypsin Inhibitors & $1.08 \mathrm{TIU} / \mathrm{mg} \pm 0.03$ \\
\hline Oxalate & $0.09 \mathrm{mg} / 100 \mathrm{~g} \pm 0.00$ \\
\hline
\end{tabular}

Table 3. Anti-nutritional contents of Blended Watermelon fruit

\begin{tabular}{|c|c|}
\hline Anti-nutrient & Amount (\%) \\
\hline Phytate & $1.28 \pm 0.02$ \\
\hline Tanin & $1.37 \pm 0.05$ \\
\hline Saponin & $0.28 \pm 0.01$ \\
\hline Alkaloid & $0.50 \pm 0.02$ \\
\hline Hydrogen Cyanide & $0.003 \pm 0.002$ \\
\hline Trypsin Inhibitors & $1.09 \mathrm{TIU} / \mathrm{mg} \pm 0.03$ \\
\hline Oxalate & $0.052 \mathrm{mg} / 100 \mathrm{~g} \pm 0.04$ \\
\hline
\end{tabular}

Table 4. Anti-nutritional contents of Blended Pawpaw fruit

\begin{tabular}{|c|c|}
\hline Anti-nutrient & Amount (\%) \\
\hline Phytate & $1.10 \pm 0.02$ \\
\hline Tanin & $0.49 \pm 0.01$ \\
\hline Saponin & $0.30 \pm 0.01$ \\
\hline Alkaloid & $0.60 \pm 0.02$ \\
\hline Hydrogen Cyanide & $0.005 \pm 0.003$ \\
\hline Trypsin Inhibitors & $1.04 \mathrm{TIU} / \mathrm{mg} \pm 0.02$ \\
\hline Oxalate & $0.55 \mathrm{mg} / 100 \mathrm{~g} \pm 0.03$ \\
\hline
\end{tabular}

Table 5. Anti-nutritional contents of Blended Pineapple fruit

\begin{tabular}{|c|c|}
\hline Anti-nutrient & Amount (\%) \\
\hline Phytate & $1.03 \pm 0.01$ \\
\hline Tanin & $0.88 \pm 0.01$ \\
\hline Saponin & $0.41 \pm 0.03$ \\
\hline Alkaloid & $0.79 \pm 0.02$ \\
\hline Hydrogen Cyanide & $0.007 \pm 0.001$ \\
\hline Trypsin Inhibitors & $1.06 \mathrm{TIU} / \mathrm{mg} \pm 0.02$ \\
\hline Oxalate & $0.079 \mathrm{mg} / 100 \mathrm{~g} \pm 0.01$ \\
\hline
\end{tabular}

anti-bacterial, anti-inflammatory and antioxidant properties [2]. The results obtained from this study have shown that the pulp of these four fruits when well blended contain a significantly high amount of phytate, tanins, alkaloid, and saponins and oxalate in that order. The level at which the other phytochemicals occur is relatively small however. There is a significant difference in the phytochemical contents in the pulp of these fruit also. Thus, the pulp and rind can contribute immensely to recommended daily allowance and maintenance of good nutritional status and hence good health for both man and animals. Watermelon, pawpaw, pineapple, and apple have important proportions of antinutrients in their pulp and with levels of anti-nutrients within safety limits as seen in this study, their consumption is therefore encouraged. Anti-nutrients like phenolic compounds are also phytochemicals that possess proven health benefits. Therefore, every part of these fruits can be used as good ingredients in formulation of health benefits food products and generally recommended for human consumption.

\section{References}

1. Umar KJ, Hassan LG, Usman H, Wasagu RSU (2013) Nutritional Composition of the Seeds of Wild Melon (Citrullus ecirrhosus) Pakistan Journal of Biological Sciences 16: $536-540$.

2. Umaru HA, Adamu R, Dahiru D, Nadro MS (2007) Level of Antinutritional Factors in Some Wild Edible Fruits of Northern Nigeria. African Journal of Biotechnology 6 : 1935-1938.

3. Wasagu RSU, Lawal M, Shehu S, Alfa HH, Muhammad C (2013) Nutritive values and Antioxidant properties of Pistiastratiotes (Water lettuce) Nigerian Journal Basic and Applied Sciences 21: 253.

4. Fergusin EL, Gibson RA, Opara-obisaw O, Stephen AM, Thomson LU (1993) The Zinc, calcium, copper,magnesium, non-starchpolysaccharide and phytate content of seventy eight locally grown and prepared African foods. Journal of Food Analysis 6: 337-342.

5. Muhammad S, Hassan LG, Dangoggo SM, Hassan, SW, Umar KJ, et al. (2011) Nutritional and Antinutritional Composition of Slerocarya birrea Seed kernel. Studia Universities "Vasile Goldis" Seria Stiintele Vietii 21: 693-699. 
6. Ali A, Deokule SS (2009) Studies on Nutritional Values of Some Wild Edible Plants from Iran and India. Pakistan Journal of Nutrition 8: 26-31.

7. Osagie AU, Okoye WL, Olawayeso BO, Awodu AO (1986) Chemical quality parameters and fatty acids composition of oils of some under exploited tropical seeds. Nigerian Journal of Applied Sciences 4: 151-162.

8. Bello MO, Falade OS, Adewusi SRA, Olawore NO (2008) Studies on the Chemical Compositions and Anti-nutrients of some lesser known Nigerian Fruits. African Journal of Biotechnology 7: 3972-3979.
9. FDA (2001) Food and Drug Administration. US Government Laws, Regulations, Decisions and Guidelines Catalog. Code of Federal Regulations. Retrieved on $22^{\text {nd }}$ September 2009.

10. FAO/WHO/UNU (1985) Energy and Protein requirements. Reports of joint FAO/ WHO/UNU Expert Consultation. Technical Report Series No. 724. Geneva.

11. Motlhanka A, Daniel O, Ebineng T (2012) Analysis of Nutrients, Total polyphenols and Antioxidant activity of Ficus sansibarica Fruits from Eastern Bostwana. Journal of Drug delivery and Therapeutics 2: 1-5.

Copyright: (C2018 Emmanuel E. This is an open-access article distributed under the terms of the Creative Commons Attribution License, which permits unrestricted use, distribution, and reproduction in any medium, provided the original author and source are credited. 